\title{
ПРОБЛЕМЫ И МЕТОДЫ ЭКСПЕРИМЕНТАЛЬНОЙ ГЕОГРАФИЧЕСКОЙ ЭКОЛОГИИ
}

\author{
(C) 2020 г. Э. Г. Коломыц* \\ Институт экологии Волжского бассейна РАН, Тольятти, Россия \\ *e-mail: egk2000@mail.ru \\ Поступила в редакцию 02.03.2018 г. \\ После доработки 21.10.2019 г. \\ Принята к публикации 28.11.2019 г.
}

\begin{abstract}
Изложена авторская парадигма экспериментальной географической экологии и ее сердцевины экологии ландшафтной. Описаны эмпирико-статистические модели и разработанные на их основе эколого-географические концепции. Они раскрывают механизмы формирования ландшафтноэкологических систем регионального и локального уровней, их естественную и антропогенную динамику, а также эволюционные тенденции. Выдвинуты и обоснованы новые положения о моно- и полисистемной организации географической среды: 1) экологические принципы и механизмы формирования зонального геопространства и его границ; 2) концепция полиморфизма ландшафтно-зональных систем как базовая модель для дальнейшего развития комплексной физической географии; 3) палеопрогнозная концепция, описывающая прогнозируемые сценарии и их палеогеографические аналоги как единую систему глобальных изменений природной среды; 4) топоэкологическая прогнозная концепция как научно-методическая основа локального геосистемного мониторинга; 5) новые положения теории устойчивости природных экосистем и методы исчисления их функциональной устойчивости на основе параметров биологического круговорота. Изложена разработанная автором и доведенная до рецептурного уровня методика численного ландшафтно-экологического прогнозирования и по ней даны региональные и локальные ландшафтно-экологические прогнозы в свете предстоящих глобальных изменений климата. Прогнозный экологический анализ проведен по моделями базовых состояний гео(эко-)систем и их климатогенных изменений, с применением методов эмпирической имитации расчетных прогнозируемых ситуаций. Предложена стратегия и разработаны алгоритмы применения методов ландшафтной экологии для количественных прогнозных оценок биотической регуляции углеродного цикла при глобальных изменениях климата. В созданных моделях географическая экология приобретает эффективный формализованный инструмент анализа и прогноза, который использует методы дискретной математики для обработки и обобщения массового эмпирического материала, получаемого при полевых и камеральных ландшафтных исследованиях.
\end{abstract}

Ключевые слова: географическая экология, экологический эксперимент, эколого-географические концепции, ландшафтно-экологическое прогнозирование, биологический круговорот, углеродный баланс, устойчивость

DOI: $10.31857 /$ S2587556620020077

\section{ВВЕДЕНИЕ}

Сближение физической географии с экологией - одна из основных тенденций современного развития наук, изучающих природную среду. Она открывает перспективы исследования природных режимов с использованием экспериментальных методов и системно-структурного анализа окружающей среды с целью оптимизации природы в ресурсном и экологическом отношениях [8], а также для разработки методологии и способов охраны природной среды и ландшафтного планирования [2]. Уже стало признанной трактовка экологии как науки о взаимодействии организмов со средой, о структуре и функциях природы, что весьма созвучно задачам учения о геосистемах. Синтез этих научных направлений привел к становлению ландшафтной экологии [4, 30, 37], одна из основных задач которой состоит в изучении структуры и функционирования природных комплексов локального уровня [26]. Мы будем придерживаться данного классического определения этой науки. По отношению же ко всей полимасштабной системе природных комплексов, начиная с ландшафтных фаций (биогеоценозов) и кончая зонально-поясными и крупными региональными единицами континентальной биосферы, примем более общее понятие географической экологии. 
В настоящей статье излагается авторская парадигма экспериментальной географической экологии и ее сердцевины - экологии ландшафтной. Основные ее положения развиты на основе синтеза географического и экологического подходов и системного анализа, оснащенного эмпирикостатистическими моделями базовых и прогнозируемых состояний гео(эко-)систем как целостных и динамичных природно-территориальных образований - в духе учений Г.Н. Высоцкого, В.В. Докучаева, Л.Г. Раменского, В.Н. Сукачева, Л.С. Берга, А.А. Григорьева, В.Н. Тимофеева-Ресовского, В.Б. Сочавы.

\section{ПРЕДМЕТ ЭКСПЕРИМЕНТАЛЬНОЙ ГЕОЭКОЛОГИИ}

В отечественной литературе широко известны обобщающие сводки по геоэкологии и экологической географии, а также связанные с ними проблемы рационального природопользования и устойчивого социально-экономического развития $[2,11,13,18$, и др.]. Эти сводки представлены в большинстве своем в виде университетских учебных пособий либо крупных академических трудов, которые стремятся охватить максимальное число современных природоохранных проблем по отечественным и международным программам и потому имеют преимущественно описательный характер. В них еще недостаточно выражены модельные аспекты рассматриваемых проблем. В современной зарубежной литературе, особенно американской, главной задачей ландшафтной экологии считается изучение прямых и обратных взаимоотношений между пространственной структурой и природными процессами [34, 37 и др.]. Кстати сказать, такой генетический подход был присущ с самого начала российской геоэкологии [4, 5, 15 и др.].

Многолетний научный поиск автора ставил одной из своих целей разработку научно-методических основ пространственного функционального геосистемного мониторинга, по определению И.П. Герасимова [8], на основе эмпирически устанавливаемых локальных и региональных ландшафтно-экологических связей. Эти связи экспериментально рассматриваются в качестве механизмов метаболической реакции природных экосистем на климатические тренды, для чего широко используются методы эмпирической имитации расчетных прогнозируемых ситуаций. В таком аспекте проблема мониторинга еще не разрабатывалась, поскольку, во-первых, отсутствовала необходимая фактологическая база, а во-вторых, - не разработана строгая методика самого локального и регионального экологического прогнозирования.

Автором создан упорядоченный ансамбль базовых и прогнозных эмпирико-статистических моделей и разработанных на их основе концеп- ций: геоэкотонной, ландшафтно-зонального полиморфизма, палеопрогнозной, прогнозно-топологической, ландшафтно-эволюционной, высокогорной геоэкологической [20-25]. Эти модели и концепции раскрывают и количественно описывают механизмы формирования ландшафтноэкологических систем как регионального, так и локального уровня, их естественную и антропогенную динамику, а также эволюционные тенденции. Ландшафтно-экологический анализ проведен на конкретных примерах, с привлечением массы аналитического и картографического материала.

Началом экспериментальных работ локального уровня служит проведение однократной крупномасштабной ландшафтно-экологической съемки, которая позволяет в короткие сроки полевых работ получить массовую экспресс-информацию о максимально возможном разнообразии состояний топогеосистем в данном регионе [22]. На региональном же уровне эколого-географические эксперименты проводятся по картографическим (ландшафтным, геоботаническим, почвенным и др.) средне- и мелкомасштабным материалам, данным гидрометеорологической сети и другим источникам [20, 21]. Здесь экспериментальные процедуры проводятся с помощью уже апробированных и вновь созданных критериев формирования региональных природно-территориальных структур.

\section{МОНО- И ПОЛИСИСТЕМНАЯ ОРГАНИЗАЦИЯ ГЕОГРАФИЧЕСКОЙ СРЕДЫ}

Прежде всего, следует остановиться на исследованиях в области географической зональности фундаментальной эколого-географической теории, выдвинутой В.В. Докучаевым $[9,15]$ и развитой А.А. Григорьевым [14] и М.И. Будыко [5]. Переосмысливание ее положений на основе регионального эмпирического моделирования и системного анализа позволило: 1) сформулировать новую модель зонального строения Русской равнины на основе теории симметрии; 2) создать кибернетическую модель природного комплекса, описывающую механизмы формирования структурных уровней природно-территориальной организации; 3) установить экологические принципы и механизмы формирования зонального географического пространства и его гранищ; 4) разработать концепцию полиморфизма ландшафтно-зональных систем как базовой модели, перспективной для дальнейшего развития комплексной физической географии и геоэкологии. Рассмотрим эти аспекты по порядку.

1. На основе проведенного по методике [31] симметрийного анализа суперпозиции двух исходных факторов регионального климатообразования: широтной зональности и долготной секторности - установлены принципиальные разли- 


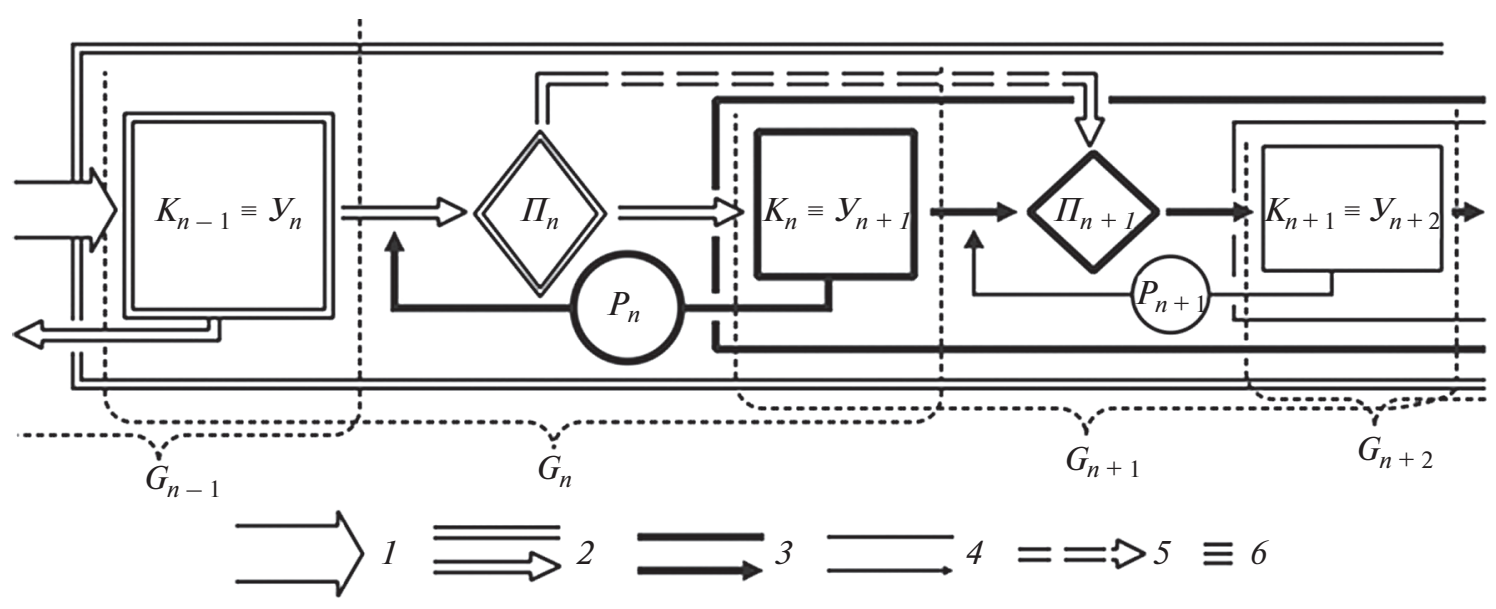

Рис. 1. Концептуальная кибернетическая модель природного комплекса как иерархической системы управления. $\mathrm{G}_{n-1}, \mathrm{G}_{n}, \ldots-$ таксономические ранги полных и неполных природных комплексов.

1-4- Очертания блоков модели и направления связей в пределах структурных уровней первого-четвертого порядков. Блоки кибернетической модели: К - ландшафтный каркас; У - ландшафтный узор; П - процессор (комплект геопотоков); Р - регулятор обратной связи. 5 - Фоновое влияние вышестоящего уровня геосистемы на нижестоящий уровень. 6 - Знак тождества.

чия в механизмах формирований зональных геопространств в “ядре типичности”, по терминологии [4], бореального пояса Русской равнины и на его южной и северной периферии (бореальном и субарктическом экотонах). Выявлено также, что очертания зональных границ имеют более высокую динамическую симметрию по сравнению с соседними зональными геопространствами. Это свойственно как всему бореальному поясу, так и его экотонам - северному и южному. Очевидно, процессы региональной диссимметризации зональных геопространств в их ядрах типичности более разнообразны и/или выражены гораздо сильнее, чем на периферии. Соответственно в зональных ядрах типичности должна быть ниже геосинэргическая гомогенность элементов ландшафтной структуры, что и подтверждается результатами исчисления природно-территориальных структур [21].

2. В качестве рабочей методической основы исследований полимасштабной природно-территориальной организации автором разработано положсение о структурных уровнях природных комплексов, опирающееся на концептуальную кибернетическую модель ландшафта как иерархическую систему управления (рис. 1). Модель имеет вид блоковой схемы фигур подобия, согласно [31], построенной путем симметричных операций скользящего отражения и переноса (трансляции) с одновременным изменением масштаба частей системы и расстояний между ними. Выбор симметрии подобия для сравнительного показа различных иерархических уровней ландшафтов исходит из самих свойств подобия системной организации географической оболочки и ее частей
[4]. Отсюда следует уже утвердившееся в физической географии представление о фоновых и пространственно-дифференцирующих свойствах одних и тех же геокомпонентов. Ландшафтообразующее значение каждого геокомпонента качественно меняется в зависимости от соотношения размеров территории и пространственных масштабов проявления его свойств.

Компоненты модели: физико-географический фон, ландшафтный каркас и ландшафтный узор, понятия относительные и имеют содержательный смысл только применительно к конкретному иерархическому уровню природного комплекса. Как правило, одно и то же свойство геокомпонента, будучи локализующим фактором для ландшафта более высокого порядка, последовательно переходит в разряд природного фона по мере снижения ранга системы (табл. 1). В первую очередь это происходит с геолого-геморфологическими факторами, а в последнюю - с биотическими компонентами. С другой стороны, геокомпоненты различаются между собой и в отношении верхнего иерархического уровня, с которого начинается их пространственно-дифференцирующее влияние. Таким образом, триада "фон-каркасузор" есть некоторая скользящая система, отображсающая соподчиненно-вложенный характер природно-территориальной организации. Отсюда следует непременно относительный характер введенного В.Б. Сочавой понятия структурного инварианта природного комплекса. Одни и те же характеристики ландшафтной структуры по отношению к одному геокомплексу могут быть эпигенетическими (функционально обусловленны- 
Таблица 1. Соотнесение разноуровенных свойств природных компонентов и факторов с таксономическим рангом ландшафтных систем*

\begin{tabular}{|c|c|c|c|c|c|c|c|c|}
\hline \multirow{2}{*}{$\begin{array}{c}\text { Природные } \\
\text { компоненты и факторы }\end{array}$} & \multicolumn{8}{|c|}{ Физико-географические единицы, по [18] } \\
\hline & $\begin{array}{c}\text { Сектор } \\
\text { и страна }\end{array}$ & $\begin{array}{c}\text { Зона } \\
\text { и подзона }\end{array}$ & $\begin{array}{c}\text { Область, } \\
\text { провинция }\end{array}$ & $\begin{array}{c}\text { Региональный } \\
\text { ландшафт }\end{array}$ & $\begin{array}{l}\text { Мест- } \\
\text { ность }\end{array}$ & $\begin{array}{l}\text { Уро- } \\
\text { чище }\end{array}$ & $\begin{array}{l}\text { Фа- } \\
\text { ция }\end{array}$ & $\begin{array}{r}\text { Биогео- } \\
\text { ценоз }\end{array}$ \\
\hline Морфоструктура I порядка & $\mathbf{y}$ & $\mathrm{K}$ & $\mathrm{K}$ & $\Phi$ & - & - & - & - \\
\hline Макроклимат & $\mathbf{y}$ & $\mathbf{y}$ & $\mathrm{K}$ & $\mathrm{K}-\Phi$ & $\Phi$ & - & - & - \\
\hline Морфоструктура II порядка & - & - & $\mathbf{y}$ & $\mathrm{K}$ & $\mathrm{K}-\Phi$ & $\Phi$ & - & - \\
\hline Большие речные бассейны & - & - & $\mathbf{y}$ & $\mathrm{K}$ & $\mathrm{K}-\Phi$ & $\Phi$ & - & - \\
\hline Морфоскульптура I порядка & - & - & - & $\mathbf{y}$ & $\mathrm{K}$ & $\Phi$ & - & - \\
\hline Мезоклимат & - & - & - & $\mathbf{y}$ & $\mathrm{K}$ & $\Phi$ & - & - \\
\hline Малые речные бассейны & - & - & - & - & $\mathbf{y}$ & $\mathrm{K}$ & $\Phi$ & - \\
\hline Морфоскульптура II порядка & - & - & - & - & - & $\mathbf{y}$ & $\mathrm{K}$ & $\Phi$ \\
\hline Растительные сообщества & - & - & - & - & - & $\mathbf{y}$ & $\mathrm{Y}-\mathrm{K}$ & $\mathrm{K}$ \\
\hline Микроклимат & - & - & - & - & - & $\mathbf{y}$ & $\mathrm{Y}-\mathrm{K}$ & $\mathrm{K}$ \\
\hline Почвенный комплекс & - & - & - & - & - & $\mathbf{y}$ & $\mathbf{y}$ & $\mathrm{Y}-\mathrm{K}$ \\
\hline Почвенно-грунтовый сток & - & - & - & - & - & $\mathbf{y}$ & $\mathbf{y}$ & $\mathrm{Y}-\mathrm{K}$ \\
\hline
\end{tabular}

* Уровни свойств: Ф - физико-географический фон; К - ландшафтный каркас; У - ландшафтный узор.

ми), а для другого, который является составной частью первого, - инвариантными.

3. Детальный разбор экологических принципов ландшафтно-зональной организации бореального экотона Русской равнины позволил вскрыть целый ряд новых закономерностей в механизмах этой организации [21]. При этом главное внимание было уделено природным границам. Рассмотрены основные "пусковые" механизмы формирования зональной границы при взаимодействии фоновых климатических сигналов и их преломлении локальными литогенными и гидроэдафическими факторами. Повышение роли локальных факторов до уровня зональнорегиональных - характерная черта периферии природной зоны, где климатический фон достигает критических значений. Выявленная функциональная система формирования зональной границы может рассматриваться как возможный механизм дифференцированных сдвигов зональных рубежей при ожидаемых глобальных изменениях климата.

Важнейшим имманентным свойством зональных границ является более сильная территориальная взаимосвязанность видов ландшафтов по обе стороны от каждой границы, а также более высокая пространственная упорядоченность ландшафтных ареалов на зональных границах по сравнению с ядрами типичности самих природных зон. Это одна из главных причин повышенной чувствительности зональных экотонов к фоновым климатическим сигналам.

Описание механизмов формирования зональной (подзональной) границы проведено с помо- щью модельного представления (рис. 2) о триггерных геосистемах и их гистерезисных свойствах $[3,6]$. Триггер есть пограничная совокупность двух альтернативных конкурирующих подсистем, находящихся в состоянии неустойчивого равновесия. Переход из одного состояния в другое называется переключением триггера. Границы геосистемы в поле ландшафтообразуюшего фактора Q определяется некоторым его критическим значением $\mathrm{Q}_{\mathrm{kp}}$, которое приурочено, в силу стохастичности ландшафтных связей, к множеству $n$ точек, находящихся на различных расстояниях $\mathrm{L}_{1}, \mathrm{~L}_{2}, \ldots, \mathrm{L}_{n}$ от начала координат в направлении градиента изменения параметра Q (см. рис. 2a). В каждой паре такой диффузной группы точек с $\mathrm{Q}_{\text {крит }}$ можно найти среднее значение этого расстояния $\left(\mathrm{L}_{\mathrm{cp}}\right)$. Траектория ординации геосистем по данному фактору в области равновесных состояний образует “складку”, или петлю гистерезиса, поэтому гистерезис рассматривается как несовпадение прямой (1) и обратной (2) траекторий смены равновесных состояний в пределах триггера (см. рис. 2б). Возникают две диффузные группы точек, с их средними расстояниями $\left(\mathrm{L}_{\mathrm{cp}}^{1}\right.$ и $\mathrm{L}_{\text {ср }}^{2}$ ), которым соответствуют неодинаковые критические значения ландшафтообразующего параметра $\left(\mathrm{Q}_{\mathrm{kp}}^{1}\right.$ и $\left.\mathrm{Q}_{\mathrm{kp}}^{2}\right)$. Разность $\mathrm{L}_{\mathrm{cp}}^{1}-\mathrm{L}_{\mathrm{cp}}^{2}$ характеризует ширину петли гистерезиса.

Гистерезисный характер триггерной полосы выражается в том, что следующая по градиенту фонового климатического фактора геосистема (или ее структурный элемент) появляется рань- 
ше, чем полностью исчезает либо утрачивает свои основные структурные элементы предыдущая система. В результате природный рубеж имеет чаще всего характер диффузной (пятнистой) полосы [6] с определенной шириной. Благодаря этому, извилистость зональной границы между ландшафтными ареалами оказывается гораздо больше тангенциальных пространственных флуктуаций (извилистости изолиний) самих климатических факторов. Это и есть результат гистерезиса зональных переходов.

4. Концепция полиморфизма ландшафтно-зональных систем основана на новом алгоритме количественной оценки форм причинности геокомпонентной ландшафтной организации. Алгоритм позволяет проводить более разносторонний анализ вертикальных ландшафтных связей, определять их “степень критичности” для устойчивого функционирования данной геосистемной структуры, давать оценку и прогноз устойчивости этих связей. Эта часть научного поиска касается основных положений моносистемной ландшафтной парадигмы - учения о природных комплексах как об относительно целостных и устойчивых сочетаниях геокомпонентов. Степень геосинэргичности моносистемных ландшафтных структур выражена через меру тесноты связей между различными геокомпонентными блоками, которая названа нами мерой их взаимной эквивалентности [21]. Разработан и апробирован достаточно простой метод расчета такой меры.

$\mathrm{C}$ ее помощью проведен опыт дифференцированной оценки моносистемной ландшафтной организации Волжского бассейна. Это позволило выявить конкретные парциальные ландшафтные структуры, образованные наиболее тесно взаимосвязанными геокомпонентами и определяющие, таким образом, лицо ландшафтно-зональных геопространств. Наряду с этим, найдены бинарные отношения компонентов с крайне низкой взаимной эквивалентностью - показателем "рыхлости" моносистемной структуры ландшафтов, относительной независимости ее элементов [21].

Предложенный способ оценки тесноты вертикальных ландшафтных связей, с ее аналитической интерпретацией, правомерно рассматривать как рабочий инструмент для изучения свойств полиморфизма (полиструктурности) ландшафта. На примере Волжского бассейна показано, что концепция полиморфизма открывает путь к переходу от единой модели природно-территориальной организации к множеству моделей, дающих более разностороннюю картину процессов дифференциации и интеграции в географической оболочке. Выделены два типа геосистемного полиморфизма: параметрический и территориальный.
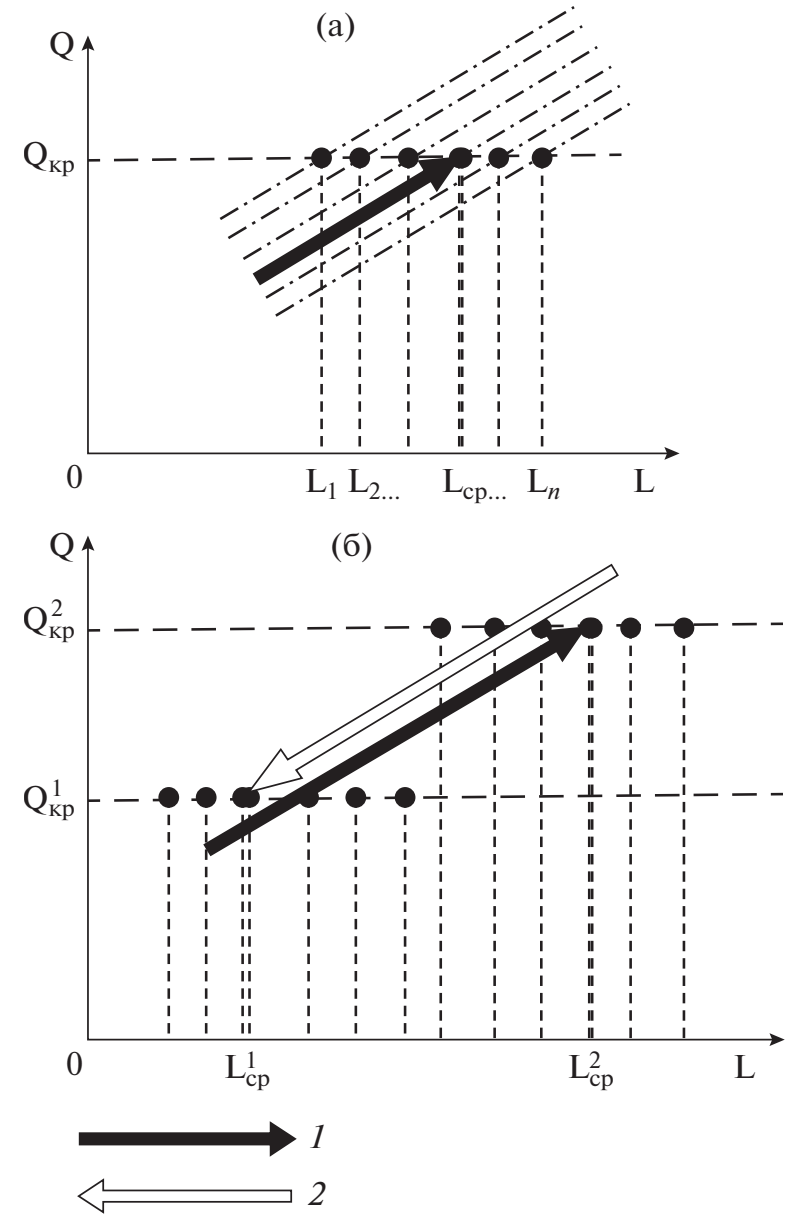

Рис. 2. Схема, иллюстрирующая триггерный характер зональной (подзональной) границы. Объяснения в тексте.

\section{МЕТОДИКА ЧИСЛЕННОГО ЭКОЛОГО- ГЕОГРАФИЧЕСКОГО ПРОГНОЗИРОВАНИЯ}

Методика доведена до рецептурного уровня и может, по-видимому, войти в научно-методический арсенал географической экологии. В ней органично сочетаются, с одной стороны, достаточно строгий формализованный подход к решению прогнозных задач, а с другой, - доступность для широкого круга исследователей процедуры сбора, обработки и анализа эмпирического материала. В отличие от известных отечественных и зарубежных подходов [19, 27, 32, 33, 38 и др.], в данной методике предусмотрен множественный характер трансформации природных комплексов при фиксированном значении климатического тренда. Разработаны два типа прогнозных моделей: хорометрический и хронометрический, - по которым представлены региональные и локальные сценарии климатогенных изменений природных комплексов Русской равнины и Большого Кавказа, в том числе его высокогорий $[17,22]$. 
Подчеркнем экспериментальный характер данной методики. В расчетных моделях ход прогнозируемых процессов воспроизводился с помощью их эмпирической имитации пространственно распределенными параметрами базовых экологических ниш изучаемых объектов. Задавались входные переменные в данную операционную систему и получали на выходе картину прогнозируемых структурных и функциональных состояний изучаемых объектов в данной статистической выборке, с выявлением новых вневыборочных объектов. Применялись: 1) локальная эмпирическая имитация регионального биоклиматического тренда по моделям бинарной гидро- и термоэдафической ординации лесных геосистем; 2) эмпирическая имитация климатогенных изменений биологического круговорота на основе гидротермического ординационного анализа его параметров; 3) эмпирическая имитация изменений продуктивности и стока углерода в лесных экосистемах при изменениях климата.

Стратегия прогноза состояла в первоначальной идентификации фитоценотических, почвенных или ландшафтных единиц определенным значениям базовых климатических условий и в последующей количественной оценке наиболее вероятных преобразований этих объектов в соответствии с ожидаемыми изменениями климата на заданные сроки. Региональными гидротермическими сигналами послужили сценарии климатических прогнозов до 2150-2200 гг. по глобальным моделям семейства AOGCMs [33]: а) экстремальной HadCM3, версия A2 [39] и б) более умеренной E GISS [36], с ее ранней версией GISS-1988 [35].

Вероятностный экологический прогноз ведется путем операций с современными и предполагаемыми гидротермическими нишами гео(эко-)систем. Для этого каждая такая ниша представляется как "размытое" (дескриптивное) множество [1] состояний системы в виде вектора-строки (или вектора-столбца). Составляющими вектора служат нормированные частные коэффициенты связи ( $C_{i j}$, см. ниже).

Выдвигаемый автором принцип ландшафтноэкологического прогнозирования гласит: климатически обусловленное функциональное преобразование одной геосистемы в другую тем значительнее, чем меньше была степень пересечения их климатических ниш в начальном состоянии и чем больше окажется величина пересечения ниш после сближения систем по данному гидротермическому признаку. Трансформация, скажем, объекта $A$ в объект $B$ должна быть тем больше, чем дальше отстояли друг от друга эти объекты в многомерном экологическом пространстве и чем ближе они окажутся в результате сдвига объекта $A$ по координатам этого пространства. Здесь объект $A$ является редуцентом, а объект $B$ - абсорбентом.
В свою очередь, объект $B$ трансформируется в объект $C$ с соответствующим смещением природных границ и т.д. В итоге вырисовывается общая картина геосистемных преобразований в регионе.

Экологические ниши состояний явления в множестве состояний данного фактора определялись с помощью бинарной ординации фактора по явлению. С этой целью по всем состояниям $x_{i}$ явления $X$, с их априорными $p\left(x_{i}\right)$ и условными $p\left(x_{i} / y_{j}\right)$ вероятностями, вычислялись частные коэффициенты связи $C\left(x_{i} / y_{j}\right)$ :

$$
C\left(x_{i} / y_{j}\right)=\frac{p\left(x_{i} / y_{j}\right)}{p\left(x_{i}\right)} .
$$

Матрица этих коэффициентов описывает систему климатических ниш фитоценозов, почв или ландшафтов в пространстве изменений данного гидротермического параметра. В дальнейшем производилось нормирование позиций каждого вектора экологических ниш явления, с получением удельных частот $C_{i j}\left(\Sigma C_{i j}=1\right)$. Градации фактора с максимальными значениями $C_{i j}$ образуют некоторую оптимальную область явления, его экологический доминант, остальные же градации относятся к "размытой” части ниши.

По каждой паре объектов $A$ и $B$ рассчитывались две прогнозные характеристики: $P_{i i} \equiv K\left(A_{0} \rightarrow A_{1}\right)-$ переход объекта $A$ самого в себя (вероятность его устойчивости) и $P_{i j} \equiv K\left(A_{0} \rightarrow B_{0}\right)-$ вероятность поглощения его другим объектом $B$ (здесь “”” знак тождества). Эти характеристики выражались следующими мерами включения (“ $\cap$ ”):

$$
\begin{gathered}
K\left(A_{0} \rightarrow A_{1}\right)=\frac{A_{0} \cap A_{1}}{A_{0}} ; \\
K\left(A_{0} \rightarrow B_{0}\right)=\frac{A_{1} \cap B_{0}-A_{0} \cap B_{0}}{A_{0}} .
\end{gathered}
$$

Переходы характеризуют степень наиболее вероятного отклонения функционального состояния той или иной экосистемы от ее современного состояния на данный прогнозный либо палеогеографический срок. В работах [20, 22, 23] приведены расчетные формулы, а также подробно изложены алгоритмы прогнозных расчетов.

Локальное прогнозное картографирование проводилось путем операций с гидротермическими нишами почв, фито- и биогеоценозов, с использованием новых методов геоморфометрии [17]. Переход же с локального уровня на региональный проводился по специально разработанному методу индукционно-иерархической экстраполяции [24]. На рис. 3 приведены фрагменты базовой карты и прогнозной ландшафтно-экологической карты северного макросклона Большого Кавказа. 
(a)

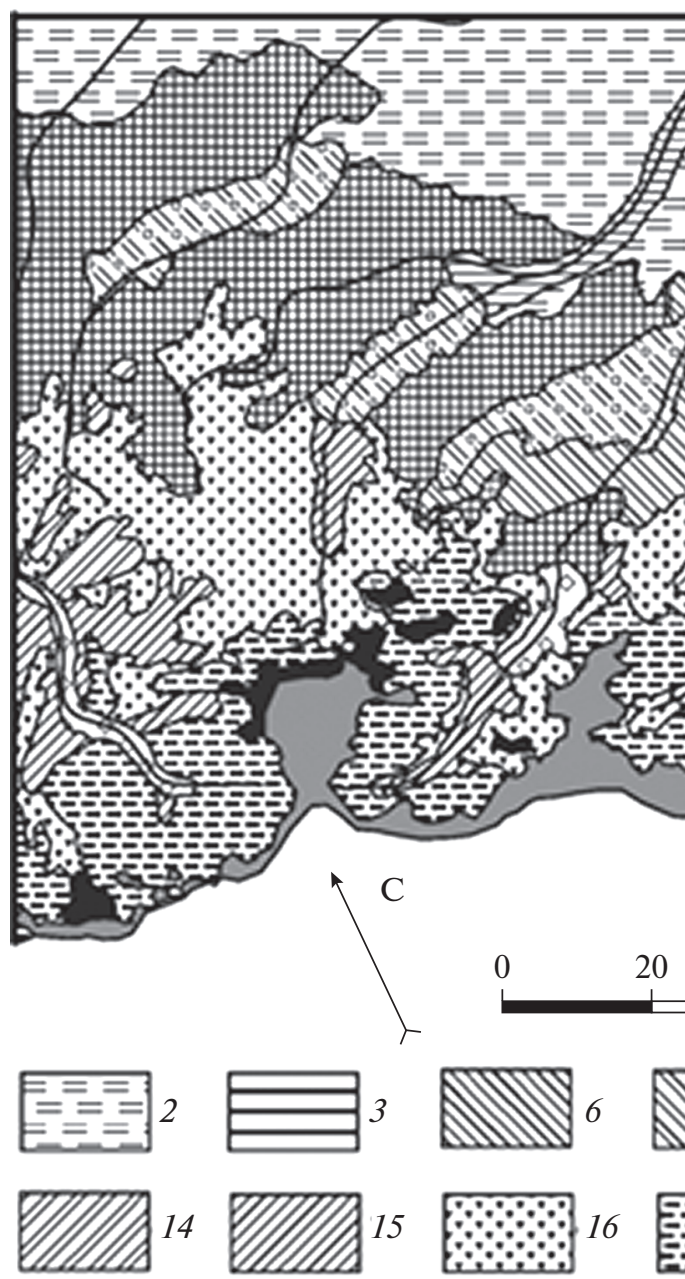

(б)

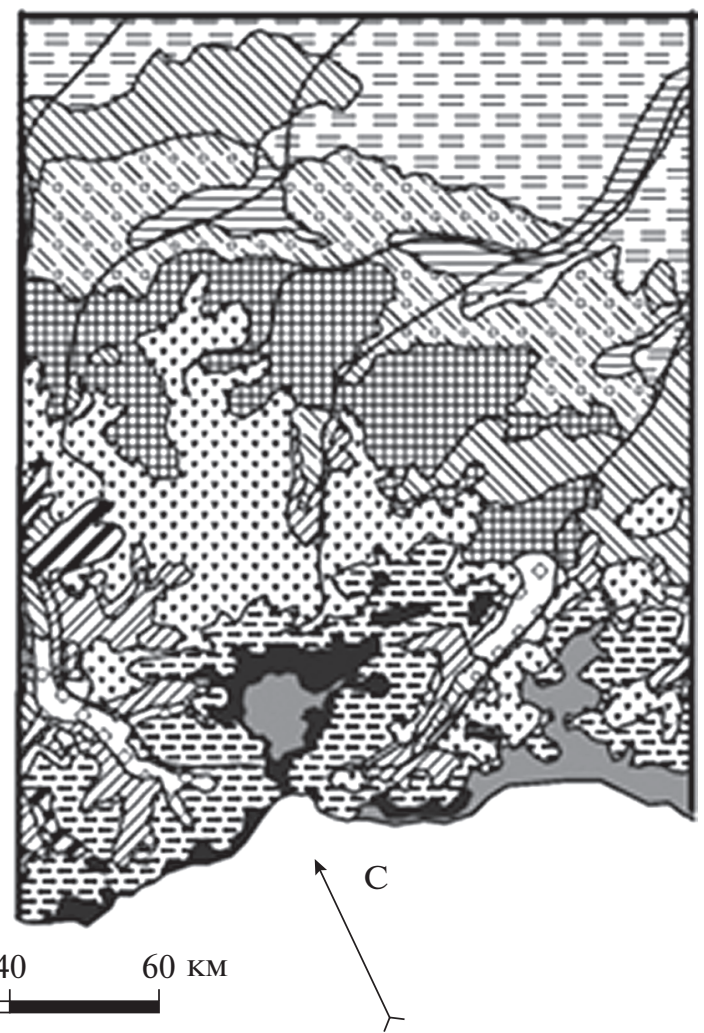

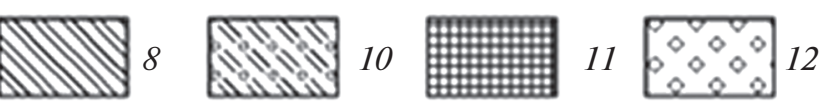

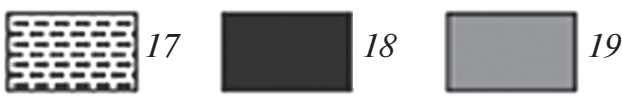

Рис. 3. Фрагменты карт Центрального Кавказа [17]: (а) - базовой ландшафтной карты; (б) - карты ландшафтно-экологических условий, прогнозируемых на 2050 г. согласно глобальной климатической модели E GISS [53].

Ландшафтные группы. Равнинно-холмистые теплоумеренные семиаридные степные: 2 - разнотравно-полынно-злаковые; 3 - разнотравно-злаковые. Нижне- и среднегорные умеренные гумидные: 6 - с дубовыми и грабово-буковыми лесами; 8 - карстовые с буковыми лесами. Горные умеренные семигумидные: 10 - горно-котловинные, с дубовыми лесами, степями, фриганой и шибляком; 11 - низко- и среднегорные, с лугостепями, кустарниками, реже с буковыми и грабово-дубовыми лесами. Горные холодно-умеренные семиаридные и семигумидные: 12 - горно-котловинные, с горно-степной и фригановой растительностью; 14 - верхнегорные, с сосновыми и березовыми лесами; 15 - верхнегорные, с сосновыми, реже березовыми лесами. Высокогорные холодные луговые: 16 - с лугами, кустарниками и редколесьем; 17 - с альпийскими лугами в комплексе с “декиани”; 18 - субнивальные. 19 - Ледники.

Установлено также, что при прогнозных оценках на первые несколько десятков лет первостепенное внимание должно быть уделено не структурной эволюции гео(эко-)систем, а направленной смене их функционирования. Речь идет об изменениях скорости малого биологического круговорота и о переходе экосистемы на новый уровень сбалансированности продукционной и детритной ветвей метаболизма. Эти процессы занимают в таежной зоне первые несколько лет, а в подзоне широколиственных лесов завершаются в течение года. Таким образом, функциональная релаксация (сдвиги в метаболизме) как первооче- редная реакция гео(эко)систем на внешнее воздействие является приоритетным объектом ландшафтно-экологического прогнозирования.

\section{ПАЛЕОПРОГНОЗНАЯ КОНЦЕПЦИЯ В РЕГИОНАЛЬНОЙ ЭКОЛОГИИ}

Одним из наиболее динамичных процессов планетарного масштаба, влиявших на эволюцию биосферы в прошлом и определяющих ее будущее состояние, является изменение климата планеты, обусловленное перестройкой химического состава атмосферы, с соответствующим проявле- 
нием ее парникового эффекта [5]. Это приводит к целому ряду крупномасштабных экологических последствий, в том числе к преобразованиям ландшафтно-зональной структуры целых континентов. Региональный отклик на глобальные изменения климата имеет вид многозначной реакции растительности, почв и в целом ландшафтов на фоновые климатические сигналы. До сих пор отсутствует сколько-нибудь ясное представление об этой многозначности. Известные на сегодняшний день прогнозно-экологические разработки носят весьма схематичный характер [10, 19, 38, и др.].

Один из путей решения этой проблемы - создание единой региональной палеопрогнозной концепции. На примере Волжского бассейна автором разработаны ландшафтно-экологические сценарии ближайшего будущего экорегионов и их палеогеографических аналогов как единой системы глобальных изменений природной среды. Основное внимание уделено механизмам сдвигов в мозаике геосистем при заданных сигналах возмущающих климатических воздействий, которые ожидаются в обозримом будущем (до середины и конца XXII в.) и аналоги которых могли иметь место в геологическом прошлом - в оптимумы микулинского межледниковья (120-130 тыс. л.н.) и голоцена (5-7 тыс. л.н.). С этой целью были разработаны региональные аналитические и картографические (в гораздо более крупном масштабе, чем это делалось до сих пор [10]) прогнозные модели ландшафтно-экологических условий, а также модели двух указанных палеогеографических срезов в свете будущих и прошлых изменений глобального климата.

Основным объектом палеопрогнозного исследования является региональная биоклиматическая система - упорядоченная совокупность пространственных связей почвенно-растительного покрова с ландшафтно-геофизическими факторами. Элементами системы служат климатические ниши фитоценологических и почвенных единиц, распределенные по гидротермическим градиентам. По аналитическим и картографическим (в масштабах $1: 2.5-6000000$ ) моделям для территории Волжского бассейна установлены закономерности функционального и структурного отклика зонально-региональных геосистем на глобальные климатические сигналы. Проведена типизация устойчивости климатических ниш бореальных и суббореальных лесных экосистем, раскрыты механизмы их преобразований при грядущих и палеогеографических сценариях изменений климата. Рассмотрены четыре основных динамических типа региональной климатической системы, обусловленные альтернативными сочетаниями термического и плювиального трендов: термо-аридный, термо-гумидный, холодно-аридный и холодно-гумидный. При росте аридности или, наоборот, гумидности климата процесс пе- рестройки растительного покрова должен иметь различный характер. В первом случае он начинается в южных (лесостепной и степной) природных зонах, во втором - в средней и южной тайге.

Исходя из фундаментальных положений теории географической зональности $[5,14,15]$, были найдены пространственные связи ландшафтнозональных систем с годовым коэффициентом атмосферного увлажнения $\left(K_{\text {увл }}\right)$. Эти связи легли в основу прогнозного и палеогеографического картографирования региональных биоклиматических условий Волжского бассейна [21]. Построение прогнозных карт по модели GISS-1988 сопровождалось созданием аналитических моделей ландшафтноэкологических переходов (рис. 4) по методике, изложенной выше.

Существенным корректирующим фактором климатогенных преобразований почвенно-растительного покрова служит функциональный изоморфизм природных экосистем. Принцип функционального изоморфизма достаточно близок известной в аутэкологии гипотезе экологического дублирования [29]. Основные структурные перестройки у геосистемы должны быть предпочтительными в направлении тех систем, которые функционально изоморфны ей, т.е. имеют с ней наибольшее сходство либо по первичной биопродуктивности, либо по параметрам нисходящей ветви метаболизма. Степень изоморфизма определялась по таксономической норме указанных функциональных параметров для рассматриваемых объектом, а также по структуре их экологических ниш в пространстве значений каждого параметра.

Согласно полученным моделям, термо-аридный биоклиматический тренд должен нарушить устойчивость лесных биогеосистем во всей переходной полосе от леса к степи на Русской равнине. На всем 100-200-километровом меридиональном пространстве юга лесной зоны ожидается прогрессирующее наступление степи на лес (см. рис. 4a). Такой ландшафтно-экологический прогноз весьма неблагоприятен для лесного хозяйства и неизбежно обострит здесь проблему сохранения лесных, а вместе с ними и водных, ресурсов. Для термо-гумидного же тренда прогнозируется существенное расширение зоны смешанных лесов. Произойдет распространение лесных экосистем в южном направлении и общее наступание леса на степь.

Построены также карты и аналитические модели зональных отклонений от базового периода на два палеогеографических среза - оптимумы микулинского межледниковья (см. рис. 4б) и голоцена. Для этих эпох выявлен попятный термоаридный тренд, т.е. ретроспективное проявление принципиально такой же тенденции, которая свойственна прогнозируемому для данной терри- 


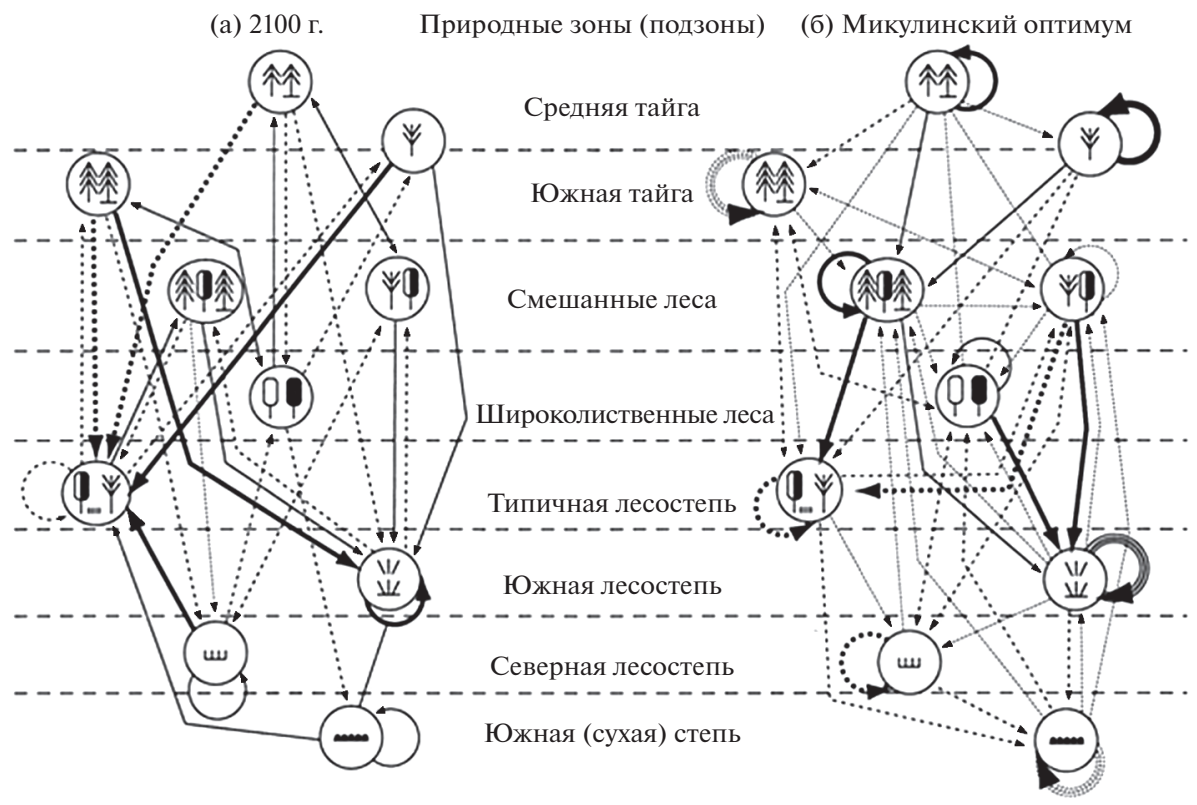

Рис. 4. Волжский бассейн и его окружение. Орграфы вероятностей функциональных переходов групп растительных формаций на прогнозный срок 2100 г. по климатической модели GISS-1993, а также их отклонений для эпохи микулинского климатического оптимума.

тории биоклиматическому тренду, но с обратным знаком. Доказано, что именно параметр $K_{\text {увл }}$, а не простое температурное сходство, как это практиковалось раньше [10], позволяет рассматривать оптимумы микулинского межледниковья и голоцена в качестве палеоаналогов прогнозируемых экологических ситуаций.

\section{КОНЦЕПЦИЯ “ГЛОБАЛЬНЫЕ ИЗМЕНЕНИЯ НА ЛОКАЛЬНОМ УРОВНЕ”}

В прогнозах экологических последствий глобального антропогенного потепления проблема локального (топологического) отклика на эти климатические изменения остается наименее освещенной. Известно, что истоки механизмов реакции природных экосистем на внешние возмущения сосредоточены на уровне элементарных хорологических единиц биосферы - биогеоценозов $[4,8]$. Между тем остается неясной реакция гидротермических ниш топогеосистем в экорегионе на поведение фоновой климатической системы. Не изучены также передаточные механизмы этой реакции. Прогнозируемый глобальный гидротермический тренд обычно описывается тремя параметрами [5, 33]: средними температурами января и июля, а также годовым количеством осадков, связь которых с биогеоценозами выражена слабо и зачастую статистически недостоверна.

Вопросы прогнозной динамики лесных экосистем в условиях меняющегося климата разработаны еще весьма слабо. Известные имитационные модели реакции лесов на климатические воздей- ствия [16, 32 и др.] отвечают узким заданным рамкам условий местообитания, поэтому результаты такого моделирования недостаточны для прогноза состояния всего биогеоценоза как целого и не охватывают пространственного многообразия его сукцессионных смен при одном и том же фоновом воздействии. Разработанный автором локальный ландшафтно-экологический прогноз основан на построении дискретных эмпирикостатистических моделей природных экосистем, по определению [28], которые позволяют получать результаты, может быть, не столь определенные во времени, но с более высоким уровнем пространственного разрешения, чем при имитационном моделировании.

С помощью ординации почвенно-фитоценологических единиц и зональных границ по пара-

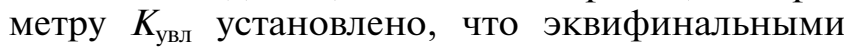
звеньями в системе региональных связей гидротермических параметров является гидроэдафические признаки: летние запасы продуктивной влаги в почве, - которые оказывают прямодействующее влияние на распределение фитоценологических и почвенных объектов. Через гидроэдафотопы осуществляется управляющее воздействие глобальной климатической системы на состояние не только региональных, но и локальных природных комплексов [20, 22].

Для проведения прогнозного анализа были использованы материалы крупномасштабных ландшафтно-экологических съемок, проведенных автором с сотрудниками в 1987-1996 гг. по специально 
разработанной методике на восьми экспериментальных полигонах Среднего и Верхнего Поволжья [22]. Аналогичные съемки были проведены в высокогорном Приэльбрусье [17], в низкогорном Нижнем Приамурье, а также на вулканическом ове Кунашир в Южно-Курильской гряде [23].

Рассмотрены пути отображения зональных биоклиматических условий в ландшафтных связях, формирующих природные комплексы локального уровня. Экспериментально показано, как местные геоморфологические и гидроэдафические факторы преломляют зональный фон и формируют региональные системы локальной зональности, состоящие из векторных рядов плакорных и экстразональных, согласно [7], биогеоценозов. Благодаря этому, на локальном уровне ландшафтной организации вырисовывается явление полизональности, которое может имитировать реакцию топогеосистем на глобальные изменения климата и может трактоваться как форма этой реакции.

Для примера приведем систему прогнозируемых климатогенных трансформаций лесных биогеоценозов (БГЦ) в Приокско-Террасном биосферном заповеднике (рис. 5). При холодноаридном тренде к сроку 2050 г. (см. рис. 5а) на фоне общей достаточно высокой устойчивости почти всех биогеоценозов (мера стабилизации составляет более 60\%) намечается определенная тенденция (до 25\%) трансформации ксероморфных трансэлювиальных песчаных зеленомошновейниковых сосновых боров (группы БГЦ-1) в соседние элювиальные мезо-гидроморфные моренные кислично-разнотравные ельники и елово-сосновые леса (группу 2). Последние же, в свою очередь, начнут преобразовываться с еще большей интенсивностью (около $30 \%$ ) в гидроморфные элювиально-аккумулятивные хвойномелколиственные кустарничково-сфагновые сообщества междуречных понижений (группу 6). В том же направлении изменятся (на 27\%) и более дренированные мезоморфные дубово-липовоберезовые леса (группа 4). К середине же XXII в., когда начнет развиваться термоаридизация (см. рис. 5б), наметятся топологические переходы, обратные первоначальным. Характерно при этом, что в ареалы группы БГЦ-1 произойдет значительное внедрение (до 48\%) уже неморальных северо-лесостепных сообществ.

Полученные результаты способны, по-видимому, дать определенный толчок к развитию прогнозного направления в топологии гео(эко-)систем как раздела комплексной физической географии и геоэкологии.

\section{БИОЛОГИЧЕСКИЙ КРУГОВОРОТ И УГЛЕРОДНЫЙ БАЛАНС ЛЕСНЫХ ЭКОСИСТЕМ ПРИ ГЛОБАЛЬНЫХ ИЗМЕНЕНИЯХ КЛИМАТА}

Впервые проведенный ландшафтно-экологический анализ феномена биотической регуляции углеродного цикла со стороны лесного покрова $[22,24]$ позволил вскрыть пространственное разнообразие механизмов интерактивного воздействия фитобиоты и почвы на углеродный обмен земной поверхности с атмосферой и выделить те механизмы, которые могут обеспечить устойчивость наземных экосистем к грядущим изменениям климата. Изложен метод расчета изменений углеродных пулов в лесных биогеоценозах, основанный на климатогенной динамике живых и мертвых фитомасс. На примере лесных экосистем Волжского бассейна разработаны прогнозные модели динамики дискретных параметров биологического круговорота и углеродного баланса для двух альтернативных климатических трендов регионального потепления и похолодания. Эти модели описывают общую будущую картину биотической регуляции углеродного цикла в системе лес-атмосфера по численным климатическим сценариям, с учетом функционально-структурных перестроек самих лесных биогеоценозов.

Установлено, что хотя детритная ветвь метаболизма наиболее чувствительна к воздействиям климата, тем не менее, за достаточно большие интервалы времени максимальные по абсолютным значениям изменения испытывает автотрофный биогенез (табл. 2). При этом львиную долю в сдвигах продуктивности составляет скелетная древесно-кустарниковая фитомасса (главным образом прирост древесины). За грядущий столетний период содержание углерода, депонированного в скелетной фитомассе лесов Среднего Поволжья, может измениться на $\pm 30-50 \%$ и более от базовой величины, что свидетельствует о существенной регулирующей роли, которую должна сыграть продуктивность бореальных и неморальных лесов региона в их углеродном обмене с атмосферой.

На основе прогнозных моделей в каждом регионе умеренного пояса Русской равнины выявляются локальные ряды и зонально-региональные типы регуляции лесным покровом содержания $\mathrm{CO}_{2}$ в атмосфере при развитии климатической термоаридизации. Установлено, что одни лесные формации могут осуществлять положительную регуляцию углеродного цикла, в соответствии с известным принципом Ле Шателье [12], а другие наоборот, регуляцию негативную. Наглядные примеры - Нижегородское Предволжье на границе подтаежной зоны с подзоной широколиственных лесов и Жигулевский низкогорный массив в южной лесостепи (см. табл. 2). Обрисована наиболее вероятная картина предполагаемой ро- 
(а) 2050 г. Холодно-аридный климатический тренд

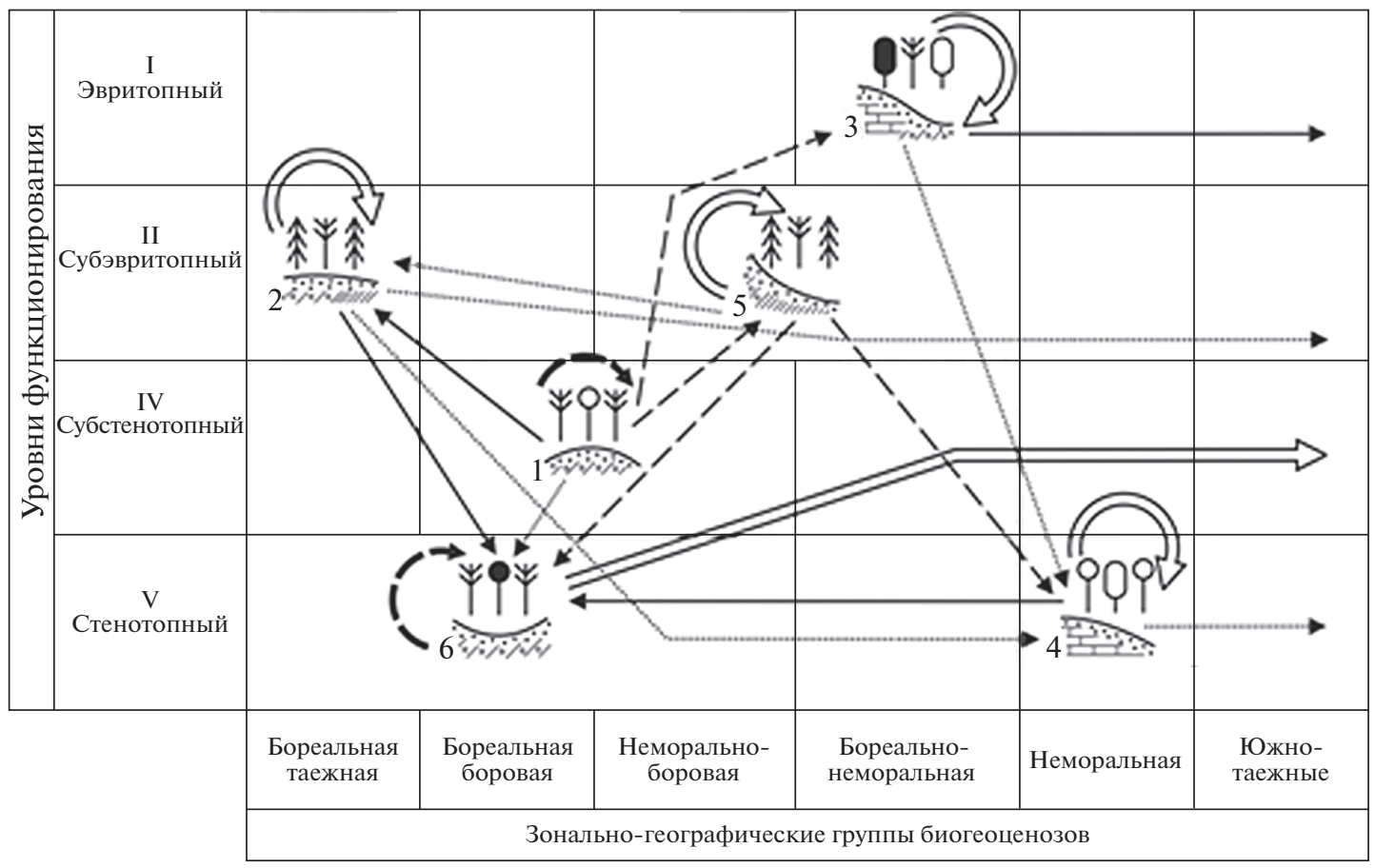

(б) 2150 г. Термоаридный климатический тренд

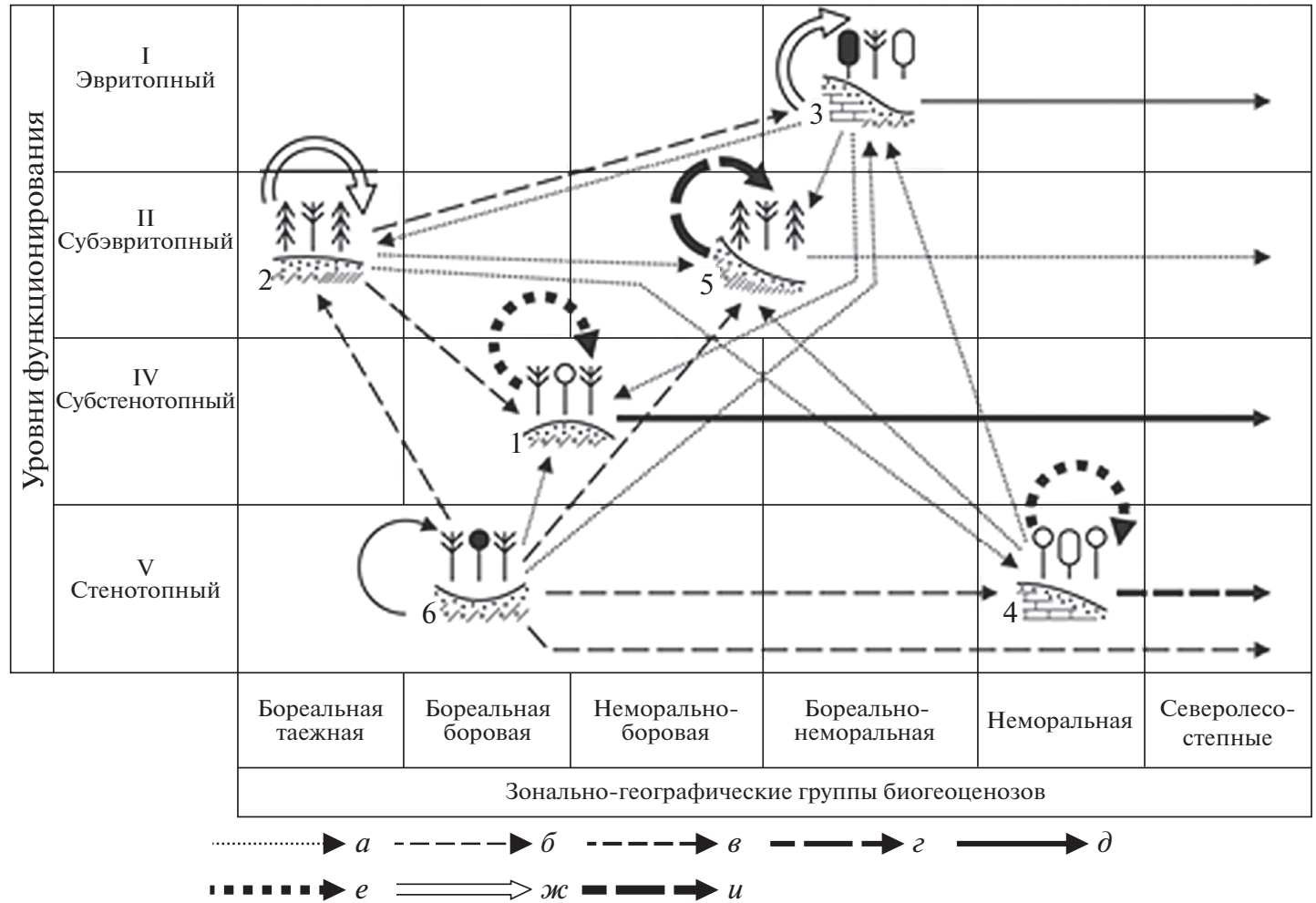

Рис. 5. Среднеокский бассейн. Экорегион Приокско-Террасного заповедника. Орграфы функциональных ландшафтно-экологических переходов, согласно прогнозно-климатической модели E GISS, между шестью группами фаций (биогеоценозов), имеющих различную зональную принадлежность и находящихся на различных уровнях базового функционирования, по терминологии [Одум Ю. Основы экологии / Под ред. Н.П. Наумова. М.: Мир, 1975. 744 с.]. Вероятности переходов: $a-0.10$ и менее; $\sigma-0.11-0.20 ; в-0.21-0.30 ; z-0.31-0.40 ; \partial-0.41-0.50 ; e-0.51-0.60 ; \rightsquigarrow-$ $0.61-0.70 ; u-0.71-0.80$.

1-6 - Группы лесных биогеоценозов. 
Таблица 2. Изменения содержания углерода (т/га) в различных лесных биогеоценозах и в их органических компонентах на трех особо охраняемых природных территориях Окско-Волжского бассейна для двух прогнозных сроков: 2050 г. (похолодание) и 2150 г. (потепление) согласно климатической модели E GISS

\begin{tabular}{|c|c|c|c|c|c|c|c|}
\hline \multicolumn{2}{|c|}{ Характеристика } & \multicolumn{2}{|c|}{$\begin{array}{c}\text { Южная граница лесостепи } \\
\text { (Национальный парк } \\
\text { "Самарская Лука") }\end{array}$} & \multicolumn{2}{|c|}{$\begin{array}{l}\text { Средняя лесостепь } \\
\text { (Национальный парк } \\
\text { "Чаваш Вармане”) }\end{array}$} & \multicolumn{2}{|c|}{$\begin{array}{c}\text { Южная граница подтайги } \\
\text { (Приокско-Террасный } \\
\text { заповедник ) }\end{array}$} \\
\hline & & 2050 г. & 2200 г. & 2050 г. & 2200 г. & 2050 г. & 2200 г. \\
\hline \multirow{7}{*}{$\begin{array}{l}\text { Группы био- } \\
\text { геоценозов } \\
\text { (типы место- } \\
\text { положений) }\end{array}$} & 1 (ТЭ) & $\begin{array}{c}9.55 \\
{[-]}\end{array}$ & $\begin{array}{c}-12.23 \\
{[-]}\end{array}$ & $\begin{array}{c}77.33 \\
{[-]}\end{array}$ & $\begin{array}{c}90.29 \\
{[+]}\end{array}$ & $\begin{array}{c}20.39 \\
{[-]}\end{array}$ & $\begin{array}{c}29.46 \\
{[+]}\end{array}$ \\
\hline & $2(\mathrm{TЭ}, Э)$ & $\begin{array}{c}-16.20 \\
{[-]}\end{array}$ & $\begin{array}{c}-38.72 \\
{[-]}\end{array}$ & $\begin{array}{c}46.83 \\
{[+]}\end{array}$ & $\begin{array}{c}63.60 \\
{[+]}\end{array}$ & $\begin{array}{c}-13.13 \\
{[+]}\end{array}$ & $\begin{array}{c}-0.44 \\
{[-]}\end{array}$ \\
\hline & $3(Э, T)$ & $\begin{array}{c}3.34 \\
{[-]}\end{array}$ & $\begin{array}{c}-27.76 \\
{[-]}\end{array}$ & $\begin{array}{c}-61.03 \\
{[+]}\end{array}$ & $\begin{array}{c}-32.51 \\
{[-]}\end{array}$ & $\begin{array}{c}-\mathbf{4 4 . 8 0} \\
{[+]}\end{array}$ & $\begin{array}{c}-27.82 \\
{[-]}\end{array}$ \\
\hline & 4 (Э-TA) & $\begin{array}{c}-15.20 \\
{[+]}\end{array}$ & $\begin{array}{c}-\mathbf{5 8 . 8 8} \\
{[+]}\end{array}$ & $\begin{array}{c}12.34 \\
{[-]}\end{array}$ & $\begin{array}{l}31.82 \\
{[+]}\end{array}$ & $\begin{array}{c}13.85 \\
{[-]}\end{array}$ & $\begin{array}{c}29.01 \\
{[+]}\end{array}$ \\
\hline & $5(\mathrm{TA}, \mathrm{A})$ & $\begin{array}{c}-36.04 \\
{[+]}\end{array}$ & $\begin{array}{c}-65.03 \\
{[-]}\end{array}$ & $\begin{array}{c}7.05 \\
{[-]}\end{array}$ & $\begin{array}{l}27.24 \\
{[+]}\end{array}$ & $\begin{array}{c}7.26 \\
{[-]}\end{array}$ & $\begin{array}{l}11.35 \\
{[+]}\end{array}$ \\
\hline & $6(\mathrm{CA}$, ЭА $)$ & $\begin{array}{l}1.22 \\
{[-]}\end{array}$ & $\begin{array}{c}-35.79 \\
{[-]}\end{array}$ & $\begin{array}{c}35.72 \\
{[-]}\end{array}$ & $\begin{array}{c}63.65 \\
{[+]}\end{array}$ & $\begin{array}{c}-26.02 \\
{[+]}\end{array}$ & $\begin{array}{l}11.82 \\
{[+]}\end{array}$ \\
\hline & Среднее & $\frac{-8.89}{[+]}$ & $\frac{-39.74}{[-]}$ & $\frac{19.71}{[-]}$ & $\frac{40.68}{[+]}$ & $\frac{-7.07}{[+]}$ & $\frac{8.90}{[+]}$ \\
\hline \multirow{7}{*}{$\begin{array}{l}\text { Фитомассы } \\
\text { (углеродные } \\
\text { пулы) }\end{array}$} & $\begin{array}{l}\text { Скелетная } \\
\text { надземная }\end{array}$ & $\begin{array}{c}-12.65 \\
{[+]}\end{array}$ & $\begin{array}{c}-22.93 \\
{[+]}\end{array}$ & $\begin{array}{l}3.56 \\
{[-]}\end{array}$ & $\begin{array}{l}21.69 \\
{[+]}\end{array}$ & $\begin{array}{c}-6.38 \\
{[+]}\end{array}$ & $\begin{array}{l}6.17 \\
{[+]}\end{array}$ \\
\hline & $\begin{array}{l}\text { Общая } \\
\text { зеленая }\end{array}$ & $\begin{array}{c}-0.57 \\
{[+]}\end{array}$ & $\begin{array}{c}-1.14 \\
{[-]}\end{array}$ & $\begin{array}{c}-0.14 \\
{[+]}\end{array}$ & $\begin{array}{l}0.12 \\
{[+]}\end{array}$ & $\begin{array}{c}-0.63 \\
{[+]}\end{array}$ & $\begin{array}{c}-0.08 \\
{[-]}\end{array}$ \\
\hline & Корневая & $\begin{array}{l}1.98 \\
{[-]}\end{array}$ & $\begin{array}{c}-5.11 \\
{[-]}\end{array}$ & $\begin{array}{l}2.92 \\
{[-]}\end{array}$ & $\begin{array}{l}5.23 \\
+1\end{array}$ & $\begin{array}{c}-1.81 \\
{[+]}\end{array}$ & $\begin{array}{l}2.19 \\
{[+]}\end{array}$ \\
\hline & $\begin{array}{l}\text { Лесная } \\
\text { подстилка }\end{array}$ & $\begin{array}{c}-1.54 \\
{[+]}\end{array}$ & $\begin{array}{l}1.38 \\
{[+]}\end{array}$ & $\begin{array}{c}-1.54 \\
{[+]}\end{array}$ & $\begin{array}{c}-3.12 \\
{[-]}\end{array}$ & $\begin{array}{c}-5.02 \\
{[+]}\end{array}$ & $\begin{array}{l}0.29 \\
{[+]}\end{array}$ \\
\hline & $\begin{array}{l}\text { Мертвая } \\
\text { надземная }\end{array}$ & $\begin{array}{c}-2.83 \\
{[+]}\end{array}$ & $\begin{array}{c}-5.36 \\
{[-]}\end{array}$ & $\begin{array}{c}24.72 \\
{[-]}\end{array}$ & $\begin{array}{c}28.62 \\
{[+]}\end{array}$ & $\begin{array}{c}-0.68 \\
{[+]}\end{array}$ & $\begin{array}{l}0.74 \\
+1\end{array}$ \\
\hline & $\begin{array}{l}\text { Лабильный } \\
\text { гумус }\end{array}$ & $\begin{array}{c}0.42 \\
{[-]}\end{array}$ & $\begin{array}{c}-6.52 \\
{[-]}\end{array}$ & $\begin{array}{c}-9.81 \\
{[+]}\end{array}$ & $\begin{array}{c}-11.85 \\
{[-]}\end{array}$ & $\begin{array}{c}7.45 \\
{[-]}\end{array}$ & $\begin{array}{c}-0.42 \\
{[-]}\end{array}$ \\
\hline & Сумма & $\frac{-8.89}{[+]}$ & $\frac{-39.74}{[-]}$ & $\frac{19.71}{[+]}$ & $\frac{40.68}{[+]}$ & $\frac{-7.07}{[+]}$ & $\frac{8.90}{[+]}$ \\
\hline
\end{tabular}

Примечание. Типы местоположений: Э - элювиальный, ТЭ - трансэлювиальный, Т - транзитный, ТА - трансаккумулятивный, А - аккумулятивный, СА - супераквальный, ЭА - элювиально-аккумулятивный. Жирным шрифтом выделены плакорные биогеоценозы. Знак [+] означает смягчение климатического тренда (положительная регуляция углеродного цикла), знак $[-]-$ его усиление (регуляция отрицательная).

ли бореальных и суббореальных лесов в снижении парникового эффекта атмосферы при глобальном потеплении, удалось также оценить, насколько в действительности леса умеренного пояса способны поддерживать устойчивость континентальной биосферы в условиях меняющегося климата, о чем до сих пор в литературе были лишь предположения.

\section{ФУНКЦИОНАЛЬНАЯ УСТОЙЧИВОСТЬ ЛЕСНЫХ ЭКОСИСТЕМ, МЕТОДЫ ЕЕ ИСЧИСЛЕНИЯ И КАРТОГРАФИРОВАНИЯ}

Устойчивость экосистемы представляет собой интегральное выражение всех ее связей со средой. Впервые в отечественной и мировой геоэкологии удалось разработать количественные мето- 
ды расчета и картографирования функциональной устойчивости лесных экосистем как целостных элементарных хорологических единиц [22, 23, 25], а не по отдельным их структурным или функциональным характеристикам, что практиковалось ранее. Данный подход является в полном смысле ландшафтно-экологическим. Его эффективность состоит в том, что он опирается на дискретные параметры биологического круговорота. С помощью метрики евклидового расстояния проведены расчеты мобильной (фитоценотической) и инерционной (почвенно-биотической) устойчивости лесных биогеоценозов двух типов: резистентной и упруго-пластичной [25]. Это позволило выявить метаболическое разнообразие указанных типов устойчивости в соответствующих индексах. Такие индексы служат комплексными показателями функционального состояния биогеоценозов в их отношениях с внешними воздействиями. По ним удалось количественно оценить относительный вклад каждого метаболического фактора в обеспечение устойчивости разного типа и провести верификацию моделей.

На основе полученных мер с помощью новых методов геоморфометрии [17] созданы крупномасштабные карты-матрицы индексов устойчивости лесных биогеоценозов двух контрастных экспериментальных полигонов на территории Волжского бассейна (в бореальном и суббореальном поясах). Переход с локального уровня на региональный проводился по уже упомянутому методу индукционно-иерархической экстраполяции. В результате построены мелкомасштабные карты-матрицы устойчивости лесных формаций бассейна, характеризующие их чувствительность к изменениям климата и функционально-восстановительный потенциал.

Интересные результаты дал анализ региональных соотношений упругой лабильной устойчивости лесных биогеоценозов и их углеродного баланса по экстремальной модели глобального потепления НadCM3, с оценкой вклада в этот баланс различных углеродных пулов (живых и мертвых фитомасс). Это позволило охарактеризовать механизмы функционирования экосистем при указанном климатическом тренде и тем самым выявить основные движушие силы положительной или отрицательной регуляции углеродного цикла со стороны лесного покрова. В пределах одного и того же экорегиона на локальном уровне складывается целый спектр взаимоотношений устойчивости лесных биогеоценозов с их углеродным балансом. В результате связи углеродного баланса с устойчивостью оказываются неоднозначными. По этим связям выделено пять типов функциональных состояний лесных биогеоценозов: деградационный, адаптивный, оптимальный, субоптимальный и пессимальный. Каждому типу отвечают определенное сочетание экстремумов их устойчивости и прогнозируемого углеродного баланса.

\section{ЗАКЛЮЧЕНИЕ}

Адресуя результаты своего поиска широкому кругу специалистов-биогеографов и физико-географов, автор стремился к тому, чтобы в созданных им ландшафтно-экологических моделях и в их содержательном анализе экспериментальная геоэкология смогла приобрести эффективный формализованный инструмент анализа и прогноза. Этот инструмент использует достаточно простые и доступные методы дискретной математики для обработки и обобщения массового эмпирического материала, получаемого при традиционных полевых и камеральных геоботанических, почвенных и ландшафтных исследованиях. Разработанные методы моделирования и результаты анализа моделей призваны служить дальнейшему развитию теории и методов географической экологии, а также региональных и локальных аспектов физики биосферы.

\section{ФИНАНСИРОВАНИЕ}

Работа выполнена при финансовой поддержке РФФИ, проект № 18-05-00024-а.

\section{FUNDING}

This work was financially supported by the Russian Foundation for Basic Research, project no. 18-05-00024-a.

\section{СПИСОК ЛИТЕРАТУРЫ}

1. Андреев В.Л. Классификационные построения в экологии и систематике. М.: Наука, 1980. 142 с.

2. Антипов А.Н., Винкельбрандт А., Дроздов А.В. и др. Ландшафтное планирование: принципы, методы, европейский и российский опыт. Иркутск: Ин-т географии СО РАН, 2002. 141 с.

3. Арманд А.Д., Ведюшкин М.А. Триггерные геосистемы. М.: Ин-т географии АН СССР, 1989. 51 с.

4. Арманд Д.Л. Наука о ландшафте. М.: Мысль, 1975. $287 \mathrm{c}$.

5. Будыко М.И. Эволюция биосферы. Л.: Гидрометеоиздат, 1984. 488 с.

6. Ведюшкин М.A. Моделирование пространственных переходов между фитоценозами // Математическое моделирование популяций растений и фитоценозов. М.: Наука, 1992. С. 24-30.

7. Высоцкий Г.Н. Избранные труды. М.: Сельхозгиз, $1960.435 \mathrm{c}$.

8. Герасимов И.П. Экологические проблемы в прошлой, настоящей и будущей географии мира. М.: Наука, 1985. 247 с.

9. Герасимов И.П. Учение Докучаева и современность. М.: Мысль, 1986. 124 с. 
10. Герасимов И.П., Величко А.А. Палеогеография Европы за последние сто тысяч лет. Атлас-монография: Наука, 1982. $156 \mathrm{c.}$

11. Голубев Г.Н. Геоэкология. М.: ГЕОС, 1999. 337 с.

12. Горшков В.Г. Физические и биологические основы устойчивости жизни. М.: Изд-во ВИНИТИ, 1995. $470 \mathrm{c.}$

13. Горшков С.П. Концептуальные основы геоэкологии. Смоленск: Изд-во СГУ, 1998. 445 с.

14. Григорьев А.А. Закономерности строения и развития географической среды. М.: Мысль, 1966. 382 с.

15. Докучаев В.В. Избранные сочинения. Картография, генезис и классификация почв. Т. III. М.: Гос. изд-во сельскохоз. лит-ры, 1949. 446 с.

16. Заварзин Г.А. Пулы и потоки углерода в наземных экосистемах России. М.: Наука, 2007. 315 с.

17. Залиханов М.Ч., Коломыи Э.Г., Шарая Л.С. и др. Высокогорная геоэкология в моделях. М.: Наука, 2010. 487 c.

18. Исаченко А.Г. Введение в экологическую географию. Учеб. пособие. СПб.: Изд-во Санкт-Петербургского ун-та, 2003. 192 с.

19. Кобак К.И., Кондрашева Н.Ю, Турчинович И.Е. Влияние изменений климата на природную зональность и экосистемы России // Изменения климата и их последствия. СПб.: Наука, 2002. С. 205-210.

20. Коломыи Э.Г. Региональная модель глобальных изменений природной среды. М.: Наука, 2003. 371 с.

21. Коломыц Э.Г. Бореальный экотон и географическая зональность: Атлас-монография. М.: Наука, 2005. 390 c.

22. Коломыи Э.Г. Локальные механизмы глобальных изменений природных экосистем. М.: Наука, 2008. $427 \mathrm{c}$.

23. Коломыи Э.Г. Тихоокеанский мегаэкотон Северной Евразии. Эволюционная модель континентальной биосферы. М.: ГЕОС, 2017. 495 с.

24. Коломыц Э.Г., Розенберг Г.С., Шарая Л.С. Методы ландшафтной экологии в прогнозных оценках биотической регуляции углеродного цикла при глобальном потеплении // Экология. 2009. Т. 40. № 6. С. 379-386.

25. Коломыи Э.Г., Керженцев А.С., Шарая Л.С. Аналитические и картографические модели функцио- нальной устойчивости лесных экосистем // Успехи соврем. биологии. 2015. Т. 135. № 1. С. 127-149.

26. Преображенский В.С. Охрана ландшафтов. Толковый словарь. М.: Прогресс, 1982. 272 с.

27. Пузаченко Ю.Г., Скулкин В.С. Структура растительности лесной зоны СССР: системный анализ. М.: Наука, 1981. 275 с.

28. Розенберг Г.С. Модели в фитоценологии. М.: Наука, 1984. 265 c.

29. Розенберг Г.С. К построению системы концепций современной экологии // Журн. общей биологии. 1991. T. 52. № 3. С. 422-440.

30. Тишков A.A., Осипов В.И. Геоэкология. Большая Российская энциклопедия. Т. 6. М.: Научное издательство “Большая Российская энциклопедия", 2006. С. 657.

31. Шубников А.В. Избранные труды по кристаллографии. М.: Наука, 1975. 551 с.

32. Bonan G.B., Polland D., Thompson S.L. Effect of boreal forest vegetation on global climate warming // Nature. 1992. № 359. P. 716-718.

33. Climate Change 1995. The Science of Climatic Change / Houghton J.T., Meira Filho L.G., Callander B.A. (eds). Cambridge, UK: Cambridge Univ. Press, 1996. 572 p.

34. Forman R.T.T., Gordon M. Landscape ecology / NY: John Wiley \& Sons, 1986. 437 p.

35. Hansen J.G., Hung I., Lasis A. et al. Global Climate Changes as Forecasted by Goddard Institute for Space Studies Three-Dimentional Models // J. Geophys. Res. 1988. V. 93. № D8. P. 9341-9354.

36. Hansen J., Sato M., Ruedy R. et al. Climate simulations for 1880-2003 with GISS model E // Climate Dynamics. 2007. V. 29. P. 661-696.

37. Hay G.J., Marceau D.J., Dube P., Bouchard A. A multiscale Framework for landscape analysis: Object-specific analysis and up scaling // Landscape Ecology. 2001. V. 16. № 6. P. 471-490.

38. Leemans $R$. Modelling ecological and agricultural impacts of global change on a global scale // J. of Sci. \& Industrial Res. V. 51. № 8-9. 1992. P. 709-724.

39. Pope V.D., Gallani M.L., Rowntree P.R., Stratton R.A. The impact of new physical parametrizations in Hadley Centre climate model - HadCM3 // Climate Dynamics. 2000. V. 16. № 2-3. P. 123-146.

\title{
Problems and Methods of Experimental Geographical Ecology
}

\author{
E. G. Kolomyts ${ }^{\#}$ \\ Institute of Ecology of the Volga River Basin, Russian Academy of Sciences, Togliatti, Russia \\ "e-mail:egk2000@mail.ru
}

\begin{abstract}
The author's paradigm of experimental geographical ecology and its core-landscape ecology-has been set forth. The empirical statistical models and the ecological geographical concepts developed on their basis are described. They disclose the mechanisms of formation of regional- and local-level landscape-ecological systems, their natural and anthropogenic dynamics and evolutionary trends. New provisions on the mono- and polysystemic organization of the geographical environment have been put forward and substantiated: 1) environmental principles and mechanisms for the formation of zonal geospace and its borders; 2) the concept of polymorphism of landscape-zonal systems as a basic model for the further development of integrated physical geography; 3) a paleo-forecasting concept that describes the predicted scenarios and their paleogeo-
\end{abstract}


graphic analogues as a single system of global changes in the environment; 4) topo-ecological forecasting concept as a scientific and methodological basis of local geosystem monitoring; 5) new provisions of the theory of sustainability of natural ecosystems and methods for calculating their functional stability based on the parameters of the biological cycle. A methodology for numerical landscape-ecological forecasting developed by the author and brought to the prescription level is presented, and regional and local landscape-ecological forecasts are given based on forthcoming global climate changes. The predictive ecological analysis was performed by models of base states of the geo(eco-)systems and there climatogenic changes, with application of methods of empirical simulation techniques for the estimated prognostic situations. A strategy is proposed, and algorithms are developed for applying landscape ecology methods for quantitative forecast estimates of the biotic regulation of the carbon cycle under global climate changes. In the constructed models, geographical ecology acquires an effective formalized tool for analysis and prediction using the methods of discrete mathematics for the processing and generalization of bulk empirical data obtained from field and laboratory landscape studies.

Keywords: geographical ecology, ecological experiment, ecological geographical concepts, landscape-ecological prediction, biological cycle, carbon balance, stability

\section{REFERENCES}

1. Andreev V.L. Klassifikatsionnye postroeniya $v$ ekologii $i$ sistematike [Classification Constructions in Ecology and Taxonomy]. Moscow: Nauka Publ., 1980. 142 p.

2. Antipov A.N., Vinkel'brandt A., Drozdov A.V., Tishkov A.A. Landshaftnoe planirovanie: printsipy, metody, evropeiskii i rossiiskii opyt [Landscape Planning: Principles, Methods, European and Russian Experience]. Irkutsk: Inst. Geogr. Sib. Otd. Akad. Nauk, 2002. 141 p.

3. Armand A.D., Vedyushkin M.A. Triggernye geosistemy [Trigger Geosystems]. Moscow: Inst. Geogr. Akad. Nauk, 1989. 51 p.

4. Armand D.L. Nauka o landshafte [Landscape Science]. Moscow: Mysl' Publ., 1975. 287 p.

5. Budyko M.I. Evolyutsiya biosfery [Evolution of Biosphere]. Leningrad: Gydrometeoizdat Publ., 1984. 488 p.

6. Vedyushkin M.A. Modeling of spatial transitions between phytocoenoses. In Matematicheskoe modelirovanie populyatsii rastenii i fitotsenozov [Mathematical Modeling of Plant Populations and Phytocenoses]. Moscow: Nauka Publ., 1992, pp. 24-30. (In Russ.).

7. Vysotskii G.N. Izbrannye Trudy [Selected Works]. Moscow: Sel'khozgiz Publ., 1960. 435 p.

8. Gerasimov I.P. Ekologicheskie problemy v proshloi, nastoyashchei i budushchei geografii mira [Ecological Problems in the Past, Present and Future Geography of the World]. Moscow: Nauka Publ., 1985. 247 p.

9. Gerasimov I.P. Uchenie Dokuchaeva i sovremennost' [The Doctrine of Dokuchaev and Modernity]. Moscow: Mysl' Publ., 1986. 124 p.

10. Paleogeografiya Evropy za poslednie sto tysyach let. Atlasmonografiya [Paleogeography of Europe over the Past Hundred Thousand Years. Atlas Monograph]. Gerasimov I.P., Velichko A.A., Eds. Moscow: Nauka Publ., 1982. $156 \mathrm{p}$.

11. Golubev G.N. Geoekologiya [Geoecology]. Moscow: GEOS Publ., 1999. 337 p.

12. Gorshkov V.G. Fizicheskie i biologicheskie osnovy ustoichivosti zhizni [Physical and Biological Basis of Life Stability]. Moscow: VINITI, 1995. 470 p.

13. Gorshkov S.P. Kontseptual'nye osnovy geoekologii [Conceptual Foundations of Geoecology]. Smolensk: Smolensk. Gos. Univ., 1988. 445 p.
14. Grigor'ev A.A. Zakonomernosti stroeniya $i$ razvitiya geograficheskoi sredy [Patterns of the Structure and Development of the Geographical Environment]. Moscow: Mysl' Publ., 1966. 382 p.

15. Dokuchaev V.V. Izbrannye Sochineniya [Selected Works]. Vol. 3: Kartografiya, genesis i klassifikatsiya pochv [Cartography, Genesis and Classification of Soils]. Moscow: Gos. Izd-vo S-kh. Literatury, 1949. $446 \mathrm{p}$.

16. Puly i potoki ugleroda $v$ nazemnykh ekosistemakh Rossii [Pools and Carbon Flows in Terrestrial Ecosystems of Russia]. Zavarzin G.A., Ed. Moscow: Nauka Publ., 2007. 315 p.

17. Zalikhanov M.Ch., Kolomyts E.G., Tsepkova N.L., Sharaya L.S., Surova N.A. Vysokogornaya geoekologiya $v$ modelyakh [High Mountain Geoecology in Models]. Moscow: Nauka Publ., 2010. 487 p.

18. Isachenko A.G. Vvedenie v ekologicheskuyu geografiyu [Introduction to Environmental Geography]. St. Petersburg: S.-Peterb. Univ., 2003. 192 p.

19. Kobak K.I., Kondrasheva N.Yu., Turchinovich I.E. The impact of climate change on the natural zonality and ecosystems of Russia. In Izmeneniya klimata $i$ ikh posledstviya [Climate Change and its Impact]. Menzhulin G.V., Ed. St. Petersburg: Nauka Publ., 2002, pp. 205-210. (In Russ.).

20. Kolomyts E.G. Regional'naya model' globalnykh izmenenii prirodnoi sredy [Regional Model of Global Environmental Changes]. Moscow: Nauka Publ., 2003. 371 p.

21. Kolomyts E.G. Boreal'nyi ekoton i geograficheskaya zonal'nost'. Atlas-monografiya [Boreal Ecotone and Geographical Zonality. Atlas-Monograph]. Moscow: Nauka Publ., 2005. 390 p.

22. Kolomyts E.G. Lokal'nye mekhanizmy global'nykh izmenenii prirodnykh ekosistem [Local Mechanisms of Global Changes in Natural Ecosystems]. Moscow: Nauka Publ., 2008. 427 p.

23. Kolomyts E.G. Tikhookeanskii megaekoton Severnoi Evrasii. Evolutsionnaya model' kontinental'noi biosfery [Pacific Mega Ecotone of the Northern Eurasia. Evolutionary Model of Continental Biosphere]. Moscow: GEOS Publ., 2017. 495 p.

24. Kolomyts E.G., Rozenberg G.S., Sharaya L.S. Methods of landscape ecology in prognostic estimation of 
the biotic regulation of the carbon cycle under conditions of global climate warming. Russ. J. Ecol., 2009, vol. 40, no. 6, pp. 379-386.

25. Kolomyts E.G., Kerzhentsev A.S., Sharaya L.S. Analytical and cartographic models of the functional sustainability of forest ecosystems. Usp. Sovrem. Biol., 2015, vol. 135, no. 1, pp. 74-96. (In Russ.).

26. Okhrana landshaftov. Tolkovyi slovar' [Protection of Landscapes. Dictionary]. Preobrazhenskii V.S., Ed. Moscow: Progress Publ., 1982. 272 p.

27. Puzachenko Yu.G., Skulkin V.S. Struktura rastitel'nosti lesnoi zony SSSR. Sistemnyi analiz [The Structure of Vegetation of the Forest Zone of the USSR: System Analysis]. Moscow: Nauka Publ., 1981. 275 p.

28. Rozenberg G.S. Modeli v fitotsenologii [Models in Phytocenology]. Moscow: Nauka Publ., 1984. 265 p.

29. Rozenberg G.S. Toward a system of concepts of modern ecology. Zh. Obshch. Biol., 1991, vol. 52, no. 3, pp. 422-440. (In Russ.).

30. Tishkov A.A., Osipov V.I. Geoecology. In Bol'shaya Rossiiskaya entsiklopediya [Great Russian Encyclopedia]. Vol. 6. Moscow: Nauch. Izd. "Bol'shaya Rossijskaya enciklopediya”, 2006, p. 657. (In Russ.).

31. Shubnikov A.V. Izbrannye Trudy po kristallografii [Selected Works on Crystallography]. Moscow: Nauka Publ., 1975. 551 p.
32. Bonan G.B., Polland D., Thompson S.L. Effect of boreal forest vegetation on global climate warming. $\mathrm{Na}$ ture, 1992, vol. 359, pp. 716-718.

33. Climate Change 1995: The Science of Climatic Change. Houghton J.T., Meira Filho L.G., Callander B.A., Harris N., Katenberg A., Maskell K., Eds. Cambridge, UK: Cambridge Univ. Press, 1996. 572 p. doi: 10.1002/j.1477-8696.1996.tb06169.x

34. Forman R.T.T., Gordon M. Landscape Ecology. New York: John Wiley \& Sons, 1986. 437 p.

35. Hansen J.G., Fung I., Lacis A., Rind D., Lebedeff S., Ruedy R., Russel G., Stone P. Global climate changes as forecasted by Goddard Institute for Space Studies threedimensional model. J. Geophys. Res., 1988, vol. 93, no. D8, pp. 9341-9354. doi: 10.1029/JD093iD08p09341

36. Hansen J., Sato M., Ruedy R., et al. Climate simulations for 1880-2003 with GISS model E. Clim. Dyn., 2007, vol. 29, pp. 661-696.

37. Hay G.J., Marceau D.J., Dube P., Bouchard A. A multiscale framework for landscape analysis: object-specific analysis and up scaling. Landsc. Ecol., 2001, vol. 16, no. 6, pp. 471-490.

38. Leemans R. Modelling ecological and agricultural impacts of global change on a glob-al scale. J. of Sci. \& Industrial Res., 1992, vol. 51, no. 8-9, pp. 709-724.

39. Pope V.D., Gallani M.L., Rowntree P.R., Stratton R.A. The impact of new physical parametrizations in Hadley Centre climate model - HadCM3. Clim. Dyn., 2000, vol. 16, no. 2-3, pp. 123-146. 